\title{
JUURNAL.RU
}

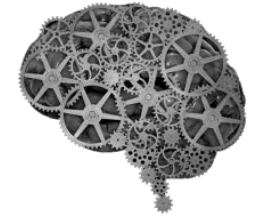

COMPANY GROUP "INTELLEKT"

Копченко Ю.Е., Бандорин М.А. Саратовский соџиально-экономический институт (филиал) РЭУ им. Г.В. Плеханова

Саратов, Россия

doi: 10.18411/lj2016-3-86

\section{Система управления кредитным риском в коммерческом банке}

Экономическое значение риска заключается в возможности управления им. Это в полной мере относится и к кредитному риску, которому подвержены все коммерческие банки без исключения. Учитывая тот факт, что кредитный риск невозможно свести к нулю, перед банками стоит задача минимизировать его до допустимых значений. Для достижения этой цели необходимо формирование эффективной системы управления кредитным риском, призванной организовать работу с кредитными активами таким образом, чтобы своевременно выявлять проблемные ссуды и лимитировать возможные риски.

Под управлением кредитным риском вообще понимают воздействие субъекта управления (персонала банка, отдела по управлению кредитным риском, руководства банка) на объект управления - кредитный риск - с целью его минимизации и лимитирования возможных убытков.

В теории и практике банковского дела вопрос о структуре системы управления кредитным риском неоднократно становился предметом рассмотрения. Так, к числу важнейших элементов системы управления рисками, как правило, относят [1]:

- принципы, правила и регламенты, которые четко документируют вопросы реализации кредитной политики банка, подходы к управлению рисками, а также организацию взаимодействия между структурными подразделениями банка, задействованными в процессе кредитования; 
- специально созданные в целях управления кредитными рисками подразделения (отделы, комитеты), деятельность которых не зависит от других подразделений банка, занимающихся оформлением и сопровождением кредитных сделок;

- процедуры информирования руководства банка о величине принятых рисков, включая процедуры принятия управленческих решений по итогам предоставленной информации;

- процедуры аудирования системы внутреннего контроля в банке, включая систему управления рисками, специализированными аудиторскими организациями, не связанными с руководством банка.

Не оспаривая правомерность описанного подхода к структурированию системы управления кредитным риском, считаем необходимым конкретизировать состав ее элементов. В целях настоящего исследования к ключевым элементам системы управления кредитным риском мы считаем необходимым отнести: кредитную политику банка; процедуры (инструменты) управления кредитным риском; эффективный ка кредитами; организационную структуру управления кредитным риском и систему принятия административных решений в сфере кредитования; методы управления кредитным риском.

Рассмотрим их подробнее.

Кредитная политика создает основу для организации процесса управления кредитами. Задача кредитной политики заключается в том, чтобы сформулировать кредитные стандарты, которыми должны руководствоваться банковские работники, отвечающие за предоставление и оформление займов, и управление ими. Когда кредитная политика сформулирована правильно и хорошо понимается на всех уровнях управления банком, то она позволяет руководству банка поддерживать правильные стандарты в области кредитов, избегать излишнего риска и верно оценивать возможности развития.

Разработка кредитной политики представляется особенно важной, когда 
банку предстоит адаптироваться к сложным и постоянно меняющимся условиям экономики и когда перед ним стоит задача, ранее никогда не возникавшая или возникавшая, но не получавшая должного внимания.

Другим элементом системы управления кредитным риском в банке являются инструменты управления. В самом общем виде инструменты управления представляют собой то, посредством чего банк воздействует на кредитный риск в целях минимизации его негативных последствий. К числу наиболее значимых инструментов управления кредитным риском относятся:

- лимитирование риска, преследующее цель установления количественных ограничений на объем риска, который банк может на себя принять;

- резервирование, которое представляет собой инструмент управления риском, основанный на удерживании части прибыли банка от распределения. В практике управления кредитным риском резервирование проявляется через механизмы создания резервов на возможные потери по ссудам;

- процедуры оценки кредитоспособности заемщиков, роль которых в системе управления кредитным риском заключается в диагностике финансового положения заемщика с целью определения его возможности по погашению кредита в будущем за счет генерирования доходов от текущей деятельности;

- инструменты хеджирования кредитного риска, основанные на производных финансовых инструментах, например таких, как кредитные деривативы;

- секьюритизация кредитов, призванная обеспечить бесперебойности выполнения банком своих функций по кредитованию экономики в условиях ограниченности долгосрочных ресурсов кредитования.

Важное место в системе управления кредитным риском занимает контроль за кредитами. В соответствии с требованиями Банка России, в рамках системы внутреннего контроля банки должны осуществлять постоянный контроль за ссудами, которым присущ повышенный риск. К их числу, в частности относятся: ссуды предоставлены связанным с банком лицам; крупные кредиты; ссуды с нестандартным порядком погашения и т.д. [2] 
Одним из элементов системы управления так же является организационная структура. Организационная структура управления рисками в каждом банке индивидуальна и определяется масштабами и спецификой его деятельности.

Крупные банки обычно имеют в своей структуре два комитета по управлению рисками: комитет по кредитному риску и комитет по управлению активами и пассивами. В функции названных комитетов входят следующие обязанности: разрабатывать внутрибанковские инструкции по управлению рисками; определять цели политики управления рисками и доводить их до сведения коллектива банка; при необходимости делегировать полномочия по реализации этой политики и контролю подразделениям и отдельным работникам банка; разрабатывать ограничения и стандарты на объемы, зоны, виды рисков, методы их оценки и регулирования.

Функции по реализации кредитной политики, разрабатываемой комитетом по кредитному риску, делегированы кредитному отделу и другим структурным подразделениям банка, которые в той или иной степени заняты в кредитном процессе или оформлении кредитной документации.

Последний, из выделенных нами, элементов системы управления кредитным риском в банке являются методы управления кредитным риском. В современной экономической литературе по банковскому менеджменту к числу основных методов управления кредитными рисками относят: разделение риска; опосредование риска; принятие обеспечения; покрытие риска посредством установления риской надбавки к процентной ставке по кредиту.

Поскольку управление рисками является частью практического менеджмента, оно требует постоянной оценки и переоценки принятых решений. В противном случае могут сложиться статистические, бюрократические и технологические иллюзии, которым не суждено осуществиться на практике. При всех существующих различиях, разработанные банками модели управления рисками должны основываться на системном подходе к организации такого управления. 


\section{Литература:}

1. Методические рекомендации по проведению проверки системы управления банковскими рисками в кредитной организации (ее филиале). Письмо ЦБР от 23 марта 2007 года №26-Т.

2. О порядке формирования кредитными организациями резервов на возможные потери по ссудам, по ссудной и приравненной к ней задолженности. Положение ЦБР от 26 марта 2004 года №254-П. 